\title{
Deep brain stimulation for the treatment of drug addiction
}

\author{
Tony R. Wang, MD, ${ }^{1}$ Shayan Moosa, MD, ${ }^{1}$ Robert F. Dallapiazza, MD, PhD, ${ }^{2}$ W. Jeffrey Elias, MD, ${ }^{1}$ \\ and Wendy J. Lynch, PhD ${ }^{3}$
}

\begin{abstract}
1Department of Neurological Surgery, University of Virginia, Charlottesville, Virginia; ${ }^{2}$ Division of Neurosurgery, Toronto Western Hospital University Health Network, Toronto, Ontario, Canada; and ${ }^{3}$ Department of Psychiatry and Neurobehavioral Sciences, University of Virginia, Charlottesville, Virginia

Drug addiction represents a significant public health concern that has high rates of relapse despite optimal medical therapy and rehabilitation support. New therapies are needed, and deep brain stimulation (DBS) may be an effective treatment. The past 15 years have seen numerous animal DBS studies for addiction to various drugs of abuse, with most reporting decreases in drug-seeking behavior with stimulation. The most common target for stimulation has been the nucleus accumbens, a key structure in the mesolimbic reward pathway. In addiction, the mesolimbic reward pathway undergoes a series of neuroplastic changes. Chief among them is a relative hypofunctioning of the prefrontal cortex, which is thought to lead to the diminished impulse control that is characteristic of drug addiction. The prefrontal cortex, as well as other targets involved in drug addiction such as the lateral habenula, hypothalamus, insula, and subthalamic nucleus have also been stimulated in animals, with encouraging results. Although animal studies have largely shown promising results, current DBS studies for drug addiction primarily use stimulation during active drug use. More data are needed on the effect of DBS during withdrawal in preventing future relapse. The published human experience for DBS for drug addiction is currently limited to several promising case series or case reports that are not controlled. Further animal and human work is needed to determine what role DBS can play in the treatment of drug addiction.
\end{abstract}

https://thejns.org/doi/abs/10.3171/2018.5.FOCUS18163

KEYWORDS deep brain stimulation; nucleus accumbens; prefrontal cortex; neuromodulation; drug addiction

$\mathrm{W}$ E are currently in the midst of a public health emergency, with opioid-related deaths skyrocketing over the past 15 years. In 2015 alone, there were upwards of 33,000 opioid-related deaths..$^{20}$ Beyond opioid addiction, alcohol, nicotine, and cocaine addiction also account for significant morbidity and mortality. 15,25

Given that current treatments - consisting of psychosocial and/or pharmacological interventions-for drug addiction have relapse rates as high as $50 \%-70 \%, 52$ additional treatments are needed. Neurosurgical procedures have been previously tried as early as the 1960s, with lesional procedures such as cingulotomy, hypothalamotomy, and resection of the substantia innominata having varying success in treating drug addiction. ${ }^{60}$ These procedures (and psychosurgery as a whole) fell out of favor with the introduction of new pharmacological treatments and concerns for ethical treatment standards. ${ }^{50,71}$ Moreover, contemporary research suggests that such destructive procedures performed for drug addiction have limited efficacy. ${ }^{38}$

Functional neurosurgery entered a new era with the in- troduction of modern-day deep brain stimulation (DBS) in the late 1980s. ${ }^{6}$ Following successful thalamic DBS for parkinsonian tremor, DBS was used at other subcortical targets for Parkinson disease (PD) and other movement disorders. DBS has a favorable safety profile compared to lesioning, and this eventually led to the implementation of DBS as an investigational treatment for neuropsychiatric disorders including depression, ${ }^{26}$ obsessive-compulsive disorder (OCD) ${ }^{16}$ and Tourette syndrome. ${ }^{55}$ The indications for DBS may yet be expanding, with several positive reports of DBS for drug addiction. ${ }^{34,49}$ In this review of DBS for drug addiction, we will highlight the neurobiology of addiction, followed by an overview of animal and human studies of DBS for drug addiction, directions for future research, and possible ethical concerns.

\section{Neurobiology of Addiction}

Drug addiction develops through a series of stages, the first of which is the binge/intoxication stage ${ }^{31}$ During

ABBREVIATIONS DBS = deep brain stimulation; DDS = dopamine dysregulation syndrome; ERN = error-related negativity; NAc = nucleus accumbens; OCD = obsessivecompulsive disorder; $\mathrm{PD}=$ Parkinson disease; $\mathrm{PFC}=$ prefrontal cortex; $\mathrm{RI}$ = reinstatement; $\mathrm{SA}=$ self-administration; $\mathrm{STN}=$ subthalamic nucleus.

SUBMITTED March 31, 2018. ACCEPTED May 21, 2018

INCLUDE WHEN CITING DOI: 10.3171/2018.5.FOCUS18163. 
this stage, drug use produces a sense of reward, mediated by dopamine increases in the mesolimbic system. ${ }^{29}$ The mesolimbic dopaminergic system is a reward circuit composed of the medial forebrain bundle, which connects the ventral tegmental area and hypothalamus with the olfactory tubercle, and the nucleus accumbens (NAc); drug-induced dopamine increases at the NAc ultimately facilitate reward. ${ }^{31,65}$ With continued drug use, prolonged and unregulated release of dopamine results in synaptic changes including elevations in mesolimbic dopaminergic excitability. ${ }^{31,73}$ This enhanced excitability is shortlived because repeated drug use leads to an attenuation of mesolimbic dopamine activity; i.e., decreases in dopamine at the NAc in response to drug use. ${ }^{46,66}$ As a result, increasing amounts of drug must be used to attain what amounts to a declining reward, or in other words, a tolerance develops.

Tolerance heralds the second stage of addiction: the withdrawal/negative affect stage. During this stage, decreased mesolimbic dopaminergic activity is hypothesized to be responsible for anhedonia and psychomotor depression. ${ }^{31,66,69}$ This negative emotional state is mediated by the activation of the extended amygdala, which includes the central nucleus of the amygdala, bed nucleus of the stria terminalis, and the medial portion (or shell) of the NAc, and is potentiated by increases in corticotropinreleasing factor, norepinephrine, and dynorphin. These neurotransmitters additionally activate stress responses, which can produce significant anxiety and irritability during withdrawal. ${ }^{31}$ Soon a conditioned negative response to withdrawal is formed, mediated by the extended amygdala and hippocampus. This learned negative response during withdrawal, coupled with tolerance, further feeds into compulsive drug-seeking behavior.

This marks the third and final stage of addiction: the preoccupation/anticipation (craving) stage. Here, the amygdala - a critical player in the withdrawal/negative affect stage-projects to the prefrontal cortex (PFC). ${ }^{9}$ The PFC-an area including the dorsolateral PFC, anterior cingulate gyrus, and medial orbitofrontal cortex-is postulated to be responsible for impulse control. However, during prolonged drug use, neuroplastic changes in the reward and memory circuits mediated by dopamine and glutamate can produce a hypofunctioning PFC, demonstrated by diminished impulse control. ${ }^{31}$ Diminished impulse control can help explain why those with addiction relapse despite known negative consequences, or why relapse may occur even after prolonged periods of drug abstinence. ${ }^{36}$ The final stage of addiction ultimately cycles back to the first, whereupon each stage and cycle can become more and more intense, with drug abstinence harder to achieve. ${ }^{30}$ Although the PFC appears to be a key player in the third stage of the addiction cycle, this final stage is fairly widespread, engaging multiple areas of the brain such as the striatum, hippocampus, insula, and habenula. ${ }^{42,50}$

Although different drugs can produce various neuroadaptive changes, and other factors such as genetics and environmental factors play a role in addiction, the above explanation provides a basic framework of understanding behind the neurobiology of addiction.

\section{Animal Studies}

To date, numerous animal studies have investigated DBS for drug addiction (Table 1), with most reporting decreases in drug-seeking behavior. Most of these studies have targeted either the NAc core or shell. 5,8,17-19,23,27,41,44,48, $62,63,70$ Although the NAc core and shell are both involved in the reward pathways and share many reciprocal connections, they are anatomically and functionally distinct, with the anterior cingulate cortex and dorsal prelimbic cortex mainly projecting to the core, and the infralimbic and ventral prelimbic cortex primarily providing afferents to the shell. ${ }^{74}$ The shell is postulated to belong more to the limbic system, whereas the core is thought to act as an interface between the motor and limbic system. This has led some to postulate that the shell mediates desire, whereas the core translates the desire into a physical action. ${ }^{4}$

Additional studies investigating other targets implicated in the neurobiology of addiction such as the lateral hypothalamus, medial PFC, ${ }^{39}$ lateral habenula, ${ }^{13}$ subthalamic nucleus (STN), ${ }^{58,67}$ and insula ${ }^{56}$ have also shown reduction in addictive behaviors (Table 1). Addictive behaviors in animals are assessed through one of three common testing strategies (Table 2). A key demarcation between these strategies is whether the drug is experimenter-administered or self-administered. In a self-administered test-the most commonly used model in DBS for drug addiction-animals are placed in a chamber with access to the drug in the form of a bottle (e.g., ethanol) or a lever press that triggers an injection via a connected intravenous catheter (e.g., cocaine). Animals spend a prolonged period within the self-administration (SA) chamber until they reach a steady state of drug intake, referred to as the SA stage. Drug availability is often then terminated and during abstinence, animals may be subjected to extinction training wherein responding on the active lever no longer produces infusion of the drug. The next testing phase is reinstatement $(\mathrm{RI})$, wherein animals are reexposed to the drug or to cues formerly associated with the drug (e.g., light paired with drug delivery; sound of the infusion pump). Interventions to treat addiction can occur during any stage. Self-administered models represent the gold standard for screening of potential treatments for drug addiction because such procedures induce features analogous to those seen in human drug addiction. Experimenter-administered testing (e.g., conditioned place preference and psychomotor sensitization), although less analogous to human drug addiction, can be useful for addressing effects on abuse potential and behavior-activating effects of drugs.

The majority of animal studies investigating DBS for drug addiction apply DBS in a self-administered model during the SA and/or RI stages. Although such experiments provide significant insights into the effect of DBS on drug addiction, they are limited in their ability to adequately replicate conditions of human drug addiction and the timing of potential DBS therapy. The SA stage correlates to the binge/intoxication stage in humans, whereas the RI stage is analogous to relapse-essentially another binge/intoxication stage. Patients who are actively abusing alcohol, opioids, stimulants, etc., would potentially be considered unfavorable candidates for DBS therapy. As 


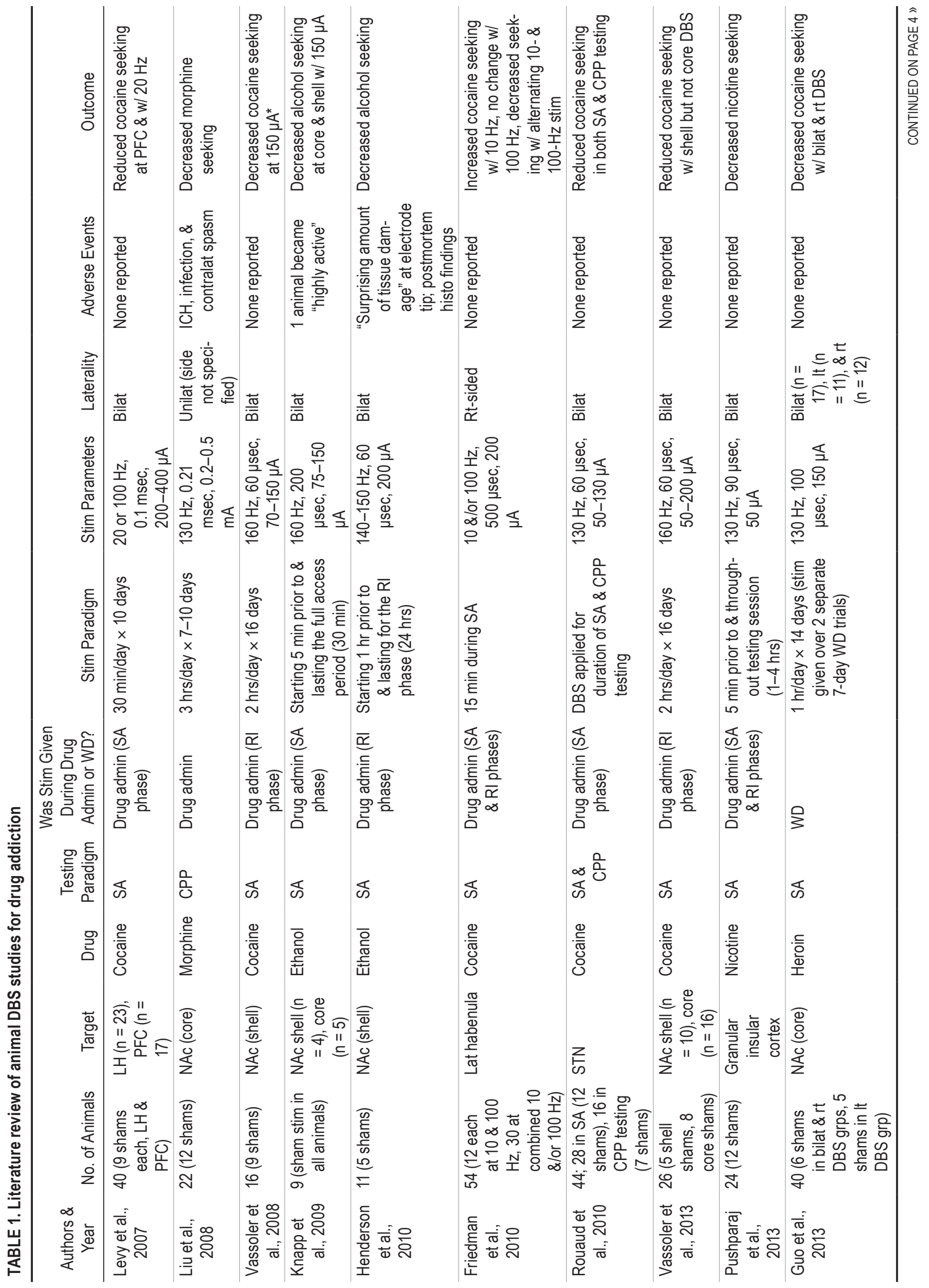




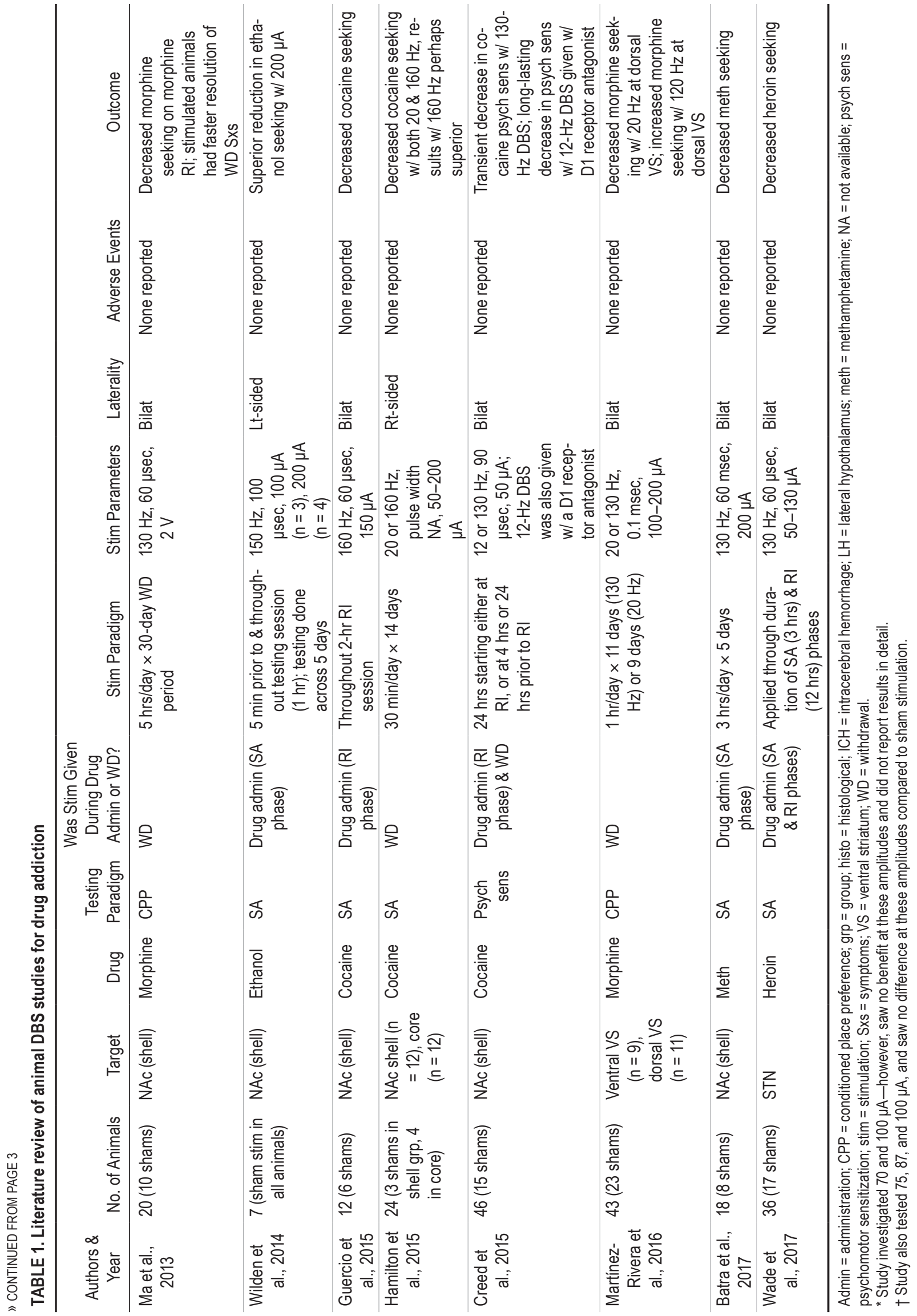


TABLE 2. Common experimental paradigms for animal drug addiction models

\begin{tabular}{lcr}
\hline Study Type & $\begin{array}{c}\text { Is Drug Self-Administered } \\
\text { or Experimenter- } \\
\text { Administered? }\end{array}$ & Outcome Measure \\
\hline SA & Self-administered & $\begin{array}{c}\text { Animal is placed in an operant conditioning test where the drug is available at set intervals. Determina- } \\
\text { tions about addictive behavior are made based on the no. of lever pushes/nose pokes, latency btwn } \\
\text { lever pushes/nose pokes, \&/or total amount of drug consumed. Lever pushes or nose pokes are mea- } \\
\text { sured if drug is given intravenously via catheter; licks are measured if drug is given orally via a bottle. }\end{array}$ \\
& $\begin{array}{c}\text { Experimenter- } \\
\text { administered }\end{array}$ & $\begin{array}{c}\text { A drug of interest is given \& associated w/ a specific context. For example, an animal is placed in a } \\
\text { chamber w/ a different color in each half, \& the drug is only given w/ the animal in the area w/ a } \\
\text { particular color. Addictive behavior is then measured by how much time the animal spends in the part } \\
\text { of the chamber associated w/ drug admin. }\end{array}$ \\
\hline $\begin{array}{l}\text { Psychomotor } \\
\text { sensitization }\end{array}$ & $\begin{array}{c}\text { Experimenter- } \\
\text { administered }\end{array}$ & $\begin{array}{c}\text { Animals are given repeated daily doses of drug until they develop increased locomotion, which is indica- } \\
\text { tive of behavioral sensitization. Addictive behavior is then gauged based on the animals' locomotor } \\
\text { activity, e.g., distance traveled. }\end{array}$ \\
\hline
\end{tabular}

such, animal studies in which DBS is applied during SA and/or RI may have limited generalizability to humans.

Perhaps a more useful DBS paradigm would be one in which stimulation was applied during withdrawal to help prevent potential relapse. ${ }^{19}$ Several studies have investigated DBS during withdrawal and have reported decreases in drug-seeking behavior. Both Guo et al..$^{18}$ and Hamilton et al. ${ }^{19}$ reported reduction in heroin- and cocaine-seeking behavior, respectively, with DBS therapy administered during withdrawal. Withdrawal during these studies lasted a total of 14 days (in Guo et al. there were two separate 7-day trials of withdrawal interrupted by an RI session, whereas in Hamilton et al. the withdrawal lasted an uninterrupted 14 days), with stimulation applied for 30-60 minutes a day. Interestingly, these studies were also among the few to investigate unilateral NAc DBS. Right-sided NAc DBS was shown to reduce heroin-seeking behavior without a significant difference compared to bilateral NAc DBS, with leftsided NAc DBS shown to be ineffective. ${ }^{18}$ Hamilton et al. also investigated low-frequency NAc DBS. Here $160-\mathrm{Hz}$ and $20-\mathrm{Hz}$ DBS were applied during a 14-day withdrawal period, and both were effective at limiting subsequent cocaine seeking during RI. ${ }^{19}$ These results support previous work in which low-frequency stimulation $(<50 \mathrm{~Hz})$ was found to suppress the NAc, albeit at a lower degree than high-frequency stimulation. ${ }^{24}$ Nevertheless, other groups have also reported positive findings when using low-frequency settings. ${ }^{8,13,39}$ Notably, however, two of these studies used low-frequency stimulation at targets other than the NAc, specifically the $\mathrm{PFC}^{39}$ and lateral habenula. ${ }^{13}$

The reason low-frequency DBS was investigated is interesting, given that many DBS stimulation parameters for movement disorders and neuropsychiatric disorders use high-frequency $(>100 \mathrm{~Hz})$ stimulation. Although highfrequency stimulation is successful, its effects are generally transient, with symptoms recurring after cessation of stimulation. ${ }^{11}$ Moreover, high-frequency stimulation is unlikely to reverse the neuroplastic changes that occur in response to addiction. ${ }^{8}$ Neuroplastic changes that occur in addiction include the potentiation of afferent axons-probably stemming from the medial $\mathrm{PFC}^{53}$ - onto D1 receptor-expressing neurons within the NAc. ${ }^{45,54}$ Creed et al. ${ }^{8}$ demonstrated that D1 receptor antagonism given with lowfrequency $(12 \mathrm{~Hz})$ stimulation attenuated cocaine psychomotor sensitization and produced long-term depression of excitatory postsynaptic potentials. Stimulation was given once during withdrawal, and animals still demonstrated reduction in cocaine-induced behavior when RI occurred 7 days later. Interestingly, when either D1 receptor antagonism or low-frequency DBS was applied in isolation, no effects were observed. Low-frequency stimulation along with D1 receptor antagonism probably worked in concert to blunt the effects of afferents from the PFC synapsing on D1 receptor-expressing neurons in the NAc. Because this study used an experimenter-administered model instead of an SA model with multiple cycles of binging and relapse, it is possible that animals may have been early enough in the addiction cycle for there to have been upregulation of the mesolimbic dopaminergic system. ${ }^{31}$ In that case, antagonism of the D1 receptors along with lowfrequency stimulation curbed addictive behaviors. If D1 receptor antagonism were used with stimulation later on in the addiction cycle when mesolimbic dopaminergic activity is decreased, ${ }^{46,66}$ it is unclear whether this experimental paradigm would produce similar results. ${ }^{57}$

This highlights an inherent weakness of many of the DBS animal studies on addiction. It is difficult to replicate the numerous cycles of binging and relapsing that characterize addiction in humans ${ }^{43}$ in a laboratory setting. With these numerous addiction cycles come neuroplastic changes such as a hypofunctioning PFC. Although the PFC has not been as frequent a target for stimulation in the treatment of addiction compared to NAc DBS, its importance is nonetheless highlighted even during NAc DBS. During NAc DBS, c-Fos immunoreactivity (a surrogate for neuronal activity) was found to be elevated not only locally at the NAc but also at the infralimbic portion of the PFC. ${ }^{48,63}$ This activation of the PFC was postulated to occur in an antidromic fashion during NAc DBS. ${ }^{63}$ This emphasizes the fact that NAc DBS may not function just through local effects only but rather through a widely dispersed network. This is additionally supported by work in which chemical silencing of the NAc (through $\gamma$-aminobutyric acid agonists and sodium channel blockers) failed to 
produce results similar to NAc DBS..$^{63}$ It should be noted, however, that others have produced results comparable to NAc DBS with chemical silencing of the NAc, ${ }^{70}$ and therefore the exact mechanism of NAc DBS for drug addiction remains to be fully elucidated.

\section{Human Studies}

The initial studies investigating DBS for addiction in humans were prompted by observations among patients with PD who were treated with DBS. Several small case series reported that STN DBS could curb symptoms of dopamine dysregulation syndrome (DDS) $)^{3,28,40,59,72}$ - a condition characterized by neuropsychiatric disturbances such as psychosis, pathological gambling, hypersexuality, mood swings, and compulsive dopamine replacement-seeking behavior. ${ }^{37}$ Subsequent larger studies with longer followup have additionally supported STN DBS as therapy for reducing impulse control disorders characteristic of DDS in patients with PD. ${ }^{1}$ The etiology of DDS is currently unknown, ${ }^{68}$ and although loss of dopaminergic tone is a hallmark for PD, there is also a relative sparing of dopaminergic neurons that project to the NAc. ${ }^{7}$ The NAc does, however, represent the primary stimulatory target of interest in non-PD-related addiction; this again was discovered through a somewhat unforeseen manner.

NAc DBS had been previously investigated as a treatment for severe medication-refractory neuropsychiatric conditions such as anxiety, depression, and OCD. ${ }^{16,26} \mathrm{In}$ several case reports, NAc DBS applied for these conditions resolved comorbid drug addiction..$^{34,47}$ In the case of addiction superimposed with OCD it could be argued that the drug addiction may have been part of the patient's compulsive behavior and that resolution of addiction may have been a mere byproduct of improvement in OCD. In one case of OCD treated with NAc DBS, significant improvement in OCD symptoms occurred 10 months before the patient ceased nicotine use. ${ }^{47}$ This suggests that the addiction may not have been part of the patient's underlying neuropsychiatric condition. In support of this, an additional patient who underwent NAc DBS for OCD and who experienced no improvement in OCD symptoms was nevertheless able to attain nicotine cessation. ${ }^{32}$ Moreover, another case report detailed resolution of alcohol dependency without any improvement in the patient's initial presenting symptoms (severe anxiety and depression) for which the NAc DBS was intended. ${ }^{34}$ A larger case series in which patients were treated with NAc DBS for neuropsychiatric conditions reported less favorable results in terms of reducing concurrent drug addiction, with more than half experiencing no change in drug use. ${ }^{32}$

Following these reports of NAc DBS improving drug addiction in the setting of comorbid neuropsychiatric disease, several small cases series or case reports documented instances of NAc DBS being used primarily for drug addiction, all with decreases in drug use (Table 3)..$^{21,33,35,49,61,64,75}$ Although promising, these studies are limited by small patient numbers, variable long-term followup, possible publication bias, and lack of blinded stimulation. There was 1 double-blinded trial of NAc DBS for cocaine dependence that used the following paradigm:
Phase I (9 months) - initial DBS implantation with optimization of stimulation parameters; Phase II (9 months) a 6-month period of double-blinded stimulation with a 3-month period of single-blinded stimulation; Phase III (12 months)-continued stimulation. At the conclusion of this 2.5-year trial, although there were objective declines in cocaine craving and usage, during the 9-month blinded period the results were equivocal, with no major differences between the "off" and "on" stimulation state, which led the investigators to conclude that there was a potential placebo effect. ${ }^{14}$

Although the placebo effect could be contributing to the results seen with NAc DBS for drug addiction, there are nevertheless neurophysiological changes that occur following NAc DBS that may explain its effect. These changes have been demonstrated by use of concurrent electroencephalography to characterize the activity of the anterior midcingulate cortex during NAc DBS. The anterior midcingulate cortex - part of the $\mathrm{PFC}-$ is postulated to be hypofunctioning in addiction, contributing to repeated relapse. Hypofunctioning of the PFC can be evaluated by error-related negativity (ERN). In brief, ERN represents a characteristic electrophysiological response produced after an erroneous answer is given, and has been shown to be reduced in patients who are in various addicted states..$^{10,12}$ This decline in ERN amplitude in drug addiction has been shown to be ameliorated by NAc DBS. ${ }^{33}$ This provides further evidence that the PFC may play a pivotal role in impulse control in drug addiction. Moreover, this result supports animal work in which NAc DBS was found to antidromically activate the PFC..$^{63}$

Neuroimaging has also demonstrated the critical role of the PFC in addiction. In 1 study, PET scans were performed during a gambling task in both the on and off stimulation state (the patient was blinded to the stimulation status during the testing) 2 years after the placement of NAc DBS for alcoholism. Testing revealed that the patient was more risk-averse and had preferential activation of the paracingulate cortex and hippocampus during stimulation. ${ }^{22}$ Although this work did not report the outcomes in regard to his alcoholism following NAc DBS, it does nonetheless highlight once again the importance of the PFC in addiction.

\section{Future Directions}

Additional preclinical and clinical studies need to be performed to establish the efficacy of DBS for drug addiction. Addiction testing in animal models consists of either experimenter-administered or self-administered paradigms. Given that self-administered experiments lend themselves more to the human state of addiction in which drugs of abuse are self-administered, this model seems more clinically relevant. Moreover, within these SA models, the vast majority of studies that have been conducted to date use DBS during the initial SA phase or the RI phase, which are analogous to the binge/intoxication phase and relapse, respectively. Instead of using DBS in these stages of addiction, future studies should investigate DBS given during the withdrawal stage, because this is the most likely stage in which DBS for addiction would be applied 
TABLE 3. Literature review of human DBS studies for drug addiction (excluding DBS for PD in which DDS was improved)

\begin{tabular}{|c|c|c|c|c|c|c|c|c|c|}
\hline $\begin{array}{l}\text { Authors \& } \\
\quad \text { Year }\end{array}$ & $\begin{array}{c}\text { No. } \\
\text { of } \\
\text { Pts }\end{array}$ & Target & $\begin{array}{l}\text { Primary } \\
\text { Indication for } \\
\text { DBS }\end{array}$ & Drug & $\begin{array}{c}\text { Stim } \\
\text { Parameters }\end{array}$ & Laterality & Adverse Events & $\begin{array}{l}\text { Duration } \\
\text { of FU }\end{array}$ & Outcome \\
\hline $\begin{array}{l}\text { Kuhn et al., } \\
2007\end{array}$ & 1 & NAc & $\begin{array}{l}\text { Severe } \\
\text { anxiety \& } \\
\text { depression }\end{array}$ & Alcohol & $\begin{array}{l}130 \mathrm{~Hz}, 90 \\
\mu \mathrm{sec}, 3 \mathrm{~V}\end{array}$ & Bilat & None reported & $12 \mathrm{mos}$ & $\begin{array}{l}\text { No change in anxiety/depression, } \\
\text { resolution of preop alcohol } \\
\text { dependency }\end{array}$ \\
\hline $\begin{array}{l}\text { Müller et al., } \\
2009\end{array}$ & 3 & NAc & Addiction & Alcohol & $\begin{array}{l}130 \mathrm{~Hz}, 90 \\
\text { usec, } \\
3.5-4.5 \mathrm{~V}\end{array}$ & Bilat & $\begin{array}{l}\text { Transient hypomania } \\
\text { in } 1 \mathrm{pt}\end{array}$ & $\begin{array}{r}12-18 \\
\text { mos }\end{array}$ & All pts improved; 2 w/ resolution \\
\hline $\begin{array}{l}\text { Kuhn et al., } \\
2009\end{array}$ & 10 & NAc & $\begin{array}{l}\text { Anxiety }(\mathrm{n}= \\
\text { 1), OCD }(\mathrm{n} \\
\quad=5), \mathrm{TS}(\mathrm{n} \\
=4)\end{array}$ & Nicotine & $\begin{array}{c}130-145 \mathrm{~Hz} \\
90 \mu \mathrm{sec} \\
(1 \text { at } 180 \\
\mu \mathrm{sec}) \\
3-6 \mathrm{~V}\end{array}$ & $\begin{array}{l}\text { Unilat \& } \\
\text { bilat } \\
\text { (5 } \\
\text { each) }\end{array}$ & None reported & $\begin{array}{r}22-33 \\
\text { mos }\end{array}$ & $\begin{array}{l}7 \text { pts were unchanged, } 3 \text { (2 OCD, } \\
1 \text { TS) had nicotine cessation; } \\
\text { of these } 3 \text { pts, } 2 \text { had unilat } \\
\text { stim (OCD); } 1 \text { pt w/ OCD who } \\
\text { quit nicotine had no improve- } \\
\text { ment in primary OCD Sxs }\end{array}$ \\
\hline $\begin{array}{l}\text { Heinze et } \\
\quad \text { al., } 2009\end{array}$ & 4 & NAc & Addiction & Alcohol & $\begin{array}{l}130 \mathrm{~Hz}, 90 \\
\text { usec, } \\
3.5-4.5 \mathrm{~V}\end{array}$ & Bilat & $\begin{array}{l}\text { DBS removed due to } \\
\text { infection in } 1 \mathrm{pt} ; \\
\text { transient hypoma- } \\
\text { nia in another }\end{array}$ & $14 \mathrm{mos}$ & $\begin{array}{l}\text { Of the } 3 \text { pts w/ DBS, } 2 \text { had com- } \\
\text { plete resolution, \& } 1 \text { had pro- } \\
\text { longed periods of abstinence } \\
\text { w/ occasional relapse }\end{array}$ \\
\hline $\begin{array}{l}\text { Mantione et } \\
\text { al., } 2010\end{array}$ & 1 & NAc & OCD & Nicotine & $\begin{array}{l}180 \mathrm{~Hz}, 90 \\
\mu \mathrm{sec} \\
3.5 \mathrm{~V}\end{array}$ & Bilat & None reported & $24 \mathrm{mos}$ & $\begin{array}{l}\text { Improvement in OCD, smoking } \\
\text { cessation achieved; did not } \\
\text { occur until } 10 \text { mos post-DBS }\end{array}$ \\
\hline $\begin{array}{l}\text { Zhou et al., } \\
\quad 2011\end{array}$ & 1 & NAc & Addiction & Heroin & $\begin{array}{l}145 \mathrm{~Hz}, 90 \\
\mu \mathrm{sec} \\
2.5 \mathrm{~V}\end{array}$ & Bilat & $\begin{array}{l}\text { Transient confusion/ } \\
\text { urinary inconti- } \\
\text { nence }\end{array}$ & 6 yrs & $\begin{array}{l}\text { Heroin cessation, which contin- } \\
\text { ued after DBS was removed } \\
\text { (3 yrs postop) per pt wishes; } \\
\text { additionally had decreased } \\
\text { cigarette smoking }\end{array}$ \\
\hline $\begin{array}{l}\text { Kuhn et al., } \\
\quad 2011\end{array}$ & 1 & NAc & Addiction & Alcohol & $\begin{array}{l}130 \mathrm{~Hz}, 120 \\
\mu \mathrm{sec} \\
5.5 \mathrm{~V}\end{array}$ & Bilat & None reported & $12 \mathrm{mos}$ & $\begin{array}{l}\text { Alcohol intake decreased after } \\
\text { stim, culminating w/ cessation } \\
\text { at } 1 \text { yr postop }\end{array}$ \\
\hline $\begin{array}{l}\text { Valencia- } \\
\text { Alfonso et } \\
\text { al., } 2012\end{array}$ & 1 & NAc & Addiction & Heroin & $\begin{array}{l}180 \mathrm{~Hz}, 90 \\
\mu \mathrm{sec} \\
3.5 \mathrm{~V}\end{array}$ & Bilat & None reported & $6 \mathrm{mos}$ & $\begin{array}{l}\text { Heroin cessation w/ exception of } \\
1 \text { relapse }\end{array}$ \\
\hline $\begin{array}{l}\text { Voges et al., } \\
2013\end{array}$ & 5 & NAc & Addiction & Alcohol & $\begin{array}{c}130 \mathrm{~Hz}, 90 \\
\mu \mathrm{sec} \\
4.5 \mathrm{~V}\end{array}$ & Bilat & $\begin{array}{l}\text { Transient hypomania } \\
\text { in } 1 \mathrm{pt}\end{array}$ & $\begin{array}{l}\text { 31-47 } \\
\quad \text { mos } \\
\text { (avg } 38 \\
\text { mos) }\end{array}$ & $\begin{array}{l}\text { All pts improved; } 2 \text { had continued } \\
\text { cessation at } 4 \text { yrs postop }\end{array}$ \\
\hline $\begin{array}{l}\text { Kuhn et al., } \\
2014\end{array}$ & 2 & NAc & Addiction & Heroin & $\begin{array}{l}140 \mathrm{~Hz}, 120 \\
\mu \mathrm{sec}, 5 \\
\mathrm{~V}(\mathrm{n}=1) \\
130 \mathrm{~Hz}, 90 \\
\mu \mathrm{sec}, 4.5 \\
\mathrm{~V}(\mathrm{n}=1)\end{array}$ & Bilat & None reported & $24 \mathrm{mos}$ & $\begin{array}{l}\text { Both pts remained off heroin \& } \\
\text { levomethadone, aside from } 1 \\
\text { relapse* }^{*}\end{array}$ \\
\hline $\begin{array}{l}\text { Gonçalves- } \\
\text { Ferreira } \\
\text { et al., } \\
2016 \dagger\end{array}$ & 1 & NAc $\ddagger$ & Addiction & Cocaine & $\begin{array}{l}150 \mathrm{~Hz}, 150 \\
\mu \mathrm{sec} \\
2.5-4 \mathrm{~V}\end{array}$ & Bilat & $\begin{array}{l}\text { Transient weight } \\
\text { gain, diminished li- } \\
\text { bido, \& unpleasant } \\
\text { warmth/flushing }\end{array}$ & 30 mos & $\begin{array}{l}\text { Decreased cocaine use/craving } \\
\text { at } 2.5 \text { yrs postop; best results } \\
\text { at contacts at NAc \& BNST }\end{array}$ \\
\hline
\end{tabular}

Avg = average; BNST = bed nucleus of the stria terminalis; FU = follow-up; pts = patients; $\mathrm{TS}=$ Tourette syndrome.

* Besides heroin, both patients also used additional drugs (the first patient additionally used alcohol and amphetamines, and the second patient additionally used amphetamines and benzodiazepines). Following NAc DBS, both patients still occasionally used these other drugs.

† This study included 6 months of double-blinded stimulation and 3 months of single-blinded stimulation. All other studies listed were retrospective case series or case reports without blinded stimulation.

$\ddagger$ Electrodes were placed such that contact 0 was at the NAc, contact 1 was at the BNST, and contacts 2 and 3 were at the anterior limb of the internal capsule. 
in humans.$^{19}$ To date, much of the human experience regarding DBS for drug addiction is based on case series or case reports without standardized outcome reporting, with limited long-term follow-up, and lack of blinding. Doubleblinding was recently used by Gonçalves-Ferreira et al..$^{14}$ in a study of NAc DBS for cocaine addiction. Although such studies have additional value, some have raised ethical concerns about double-blinded studies and sham surgery, because patients may be exposed to potential serious risks without any therapeutic benefits. ${ }^{50}$ Beyond this are ethical and logistical concerns that pertain especially to DBS for addiction. DBS may not be well suited for patients who are actively abusing drugs, and furthermore if DBS were to be used in this population, there would be concerns regarding the patient's ability to give informed consent while under the influence of drug(s). Such matters may be mitigated provided that DBS is used for patients in withdrawal, seeking to prevent further relapse. However, some have noted that patients who rapidly undergo drug detoxification may still have alterations in mental status and/or executive function, limiting their ability to provide informed consent. ${ }^{50}$

This highlights another ethical and logistical issue surrounding DBS for addiction: when is the appropriate time for this therapy? For patients who recently attained drug abstinence, the chance of drug relapse is relatively high compared to patients with long-term drug abstinence. Accordingly, DBS for patients in acute withdrawal has a higher chance of "failure," if one considers failure as drug relapse. However, newly drug-abstinent patients stand to benefit the most because DBS could prevent future relapse. For long-term drug abstainers, although DBS is less likely to "fail," its benefits may be marginal-some might argue that whatever treatments provided for prolonged drug abstinence would have continued to do so in the absence of DBS. Other ethical concerns regarding DBS for addiction surround the notion that, through targeting and alteration of the brain's reward centers, DBS may alter a person's sense of identity.$^{50}$ Last there is the issue of patient-controlled stimulation that, although common in DBS for movement disorders, may not be prudent in the addiction population because patients in theory could switch off their stimulation, leading to possible drug relapse. These ethical concerns are best addressed using a multidisciplinary team approach in which consensus criteria for inclusion or exclusion and standardized outcome measures are developed. Future studies may also benefit from multicenter collaborative efforts to help with patient recruitment.

Although the NAc has been the most popular target in both animal and human studies on DBS for addiction, other targets warrant further investigation. Chief among these would be the PFC, because animal studies have shown that direct stimulation of the PFC can reduce addictive behavior, ${ }^{39}$ and that the effects of NAc DBS may be mediated in part by activation of the PFC..$^{63}$ Although the PFC has yet to be directly stimulated for addiction in humans, noninvasive studies of the PFC during NAc DBS have demonstrated that the PFC is responsible for modulating behavior that may be behind relapse. ${ }^{22,33}$ Beyond the PFC, the insula, which in one animal experiment was shown to be an efficacious stimulation target, ${ }^{56}$ may also merit more preclinical investigation because human stud- ies have demonstrated that those with insular lesions may have dramatic resolution of nicotine addiction and experience milder withdrawal symptoms, perhaps further implicating the insula's role in addiction. ${ }^{2,51}$

\section{Conclusions}

Drug addiction remains a significant public health concern, with significant morbidity and mortality. Current therapies for drug addiction have high rates of relapse, and therefore within the past 15 years DBS has been investigated as a potential treatment. Much of the preclinical data has been promising; however, DBS has yet to be widely used in humans for drug addiction. The human experience with DBS for drug addiction is primarily limited to case reports without blinded assessments or standardized outcome measures. Additional preclinical and clinical research needs to occur in order to determine the role of DBS in the treatment of drug addiction.

\section{References}

1. Abbes M, Lhommée E, Thobois S, Klinger H, Schmitt E, Bichon A, et al: Subthalamic stimulation and neuropsychiatric symptoms in Parkinson's disease: results from a long-term follow-up cohort study. J Neurol Neurosurg Psychiatry [epub ahead of print], 2018

2. Abdolahi A, Williams GC, Benesch CG, Wang HZ, Spitzer EM, Scott BE, et al: Damage to the insula leads to decreased nicotine withdrawal during abstinence. Addiction 110:19942003, 2015

3. Bandini F, Primavera A, Pizzorno M, Cocito L: Using STN DBS and medication reduction as a strategy to treat pathological gambling in Parkinson's disease. Parkinsonism Relat Disord 13:369-371, 2007

4. Bari A, Niu T, Langevin JP, Fried I: Limbic neuromodulation: implications for addiction, posttraumatic stress disorder, and memory. Neurosurg Clin N Am 25:137-145, 2014

5. Batra V, Tran TL, Caputo J, Guerin GF, Goeders NE, Wilden $\mathrm{J}$ : Intermittent bilateral deep brain stimulation of the nucleus accumbens shell reduces intravenous methamphetamine intake and seeking in Wistar rats. J Neurosurg 126:13391350,2017

6. Benabid AL, Pollak P, Louveau A, Henry S, de Rougemont $\mathrm{J}$ : Combined (thalamotomy and stimulation) stereotactic surgery of the VIM thalamic nucleus for bilateral Parkinson disease. Appl Neurophysiol 50:344-346, 1987

7. Bonci A, Singh V: Dopamine dysregulation syndrome in Parkinson's disease patients: from reward to penalty. Ann Neurol 59:733-734, 2006

8. Creed M, Pascoli VJ, Lüscher C: Addiction therapy. Refining deep brain stimulation to emulate optogenetic treatment of synaptic pathology. Science 347:659-664, 2015

9. Everitt BJ, Wolf ME: Psychomotor stimulant addiction: a neural systems perspective. J Neurosci 22:3312-3320, 2002

10. Fein G, Chang M: Smaller feedback ERN amplitudes during the BART are associated with a greater family history density of alcohol problems in treatment-naïve alcoholics. Drug Alcohol Depend 92:141-148, 2008

11. Follett KA: The surgical treatment of Parkinson's disease. Annu Rev Med 51:135-147, 2000

12. Forman SD, Dougherty GG, Casey BJ, Siegle GJ, Braver TS, Barch DM, et al: Opiate addicts lack error-dependent activation of rostral anterior cingulate. Biol Psychiatry 55:531537,2004

13. Friedman A, Lax E, Dikshtein Y, Abraham L, Flaumenhaft Y, Sudai E, et al: Electrical stimulation of the lateral haben- 
ula produces enduring inhibitory effect on cocaine seeking behavior. Neuropharmacology 59:452-459, 2010

14. Gonçalves-Ferreira A, do Couto FS, Rainha Campos A, Lucas Neto LP, Gonçalves-Ferreira D, Teixeira J: Deep brain stimulation for refractory cocaine dependence. Biol Psychiatry 79:e87-e89, 2016

15. Grant BF, Chou SP, Saha TD, Pickering RP, Kerridge BT, Ruan WJ, et al: Prevalence of 12-month alcohol use, highrisk drinking, and DSM-IV alcohol use disorder in the United States, 2001-2002 to 2012-2013: results from the National Epidemiologic Survey on Alcohol and Related Conditions. JAMA Psychiatry 74:911-923, 2017

16. Greenberg BD, Malone DA, Friehs GM, Rezai AR, Kubu CS, Malloy PF, et al: Three-year outcomes in deep brain stimulation for highly resistant obsessive-compulsive disorder. Neuropsychopharmacology 31:2384-2393, 2006

17. Guercio LA, Schmidt HD, Pierce RC: Deep brain stimulation of the nucleus accumbens shell attenuates cue-induced reinstatement of both cocaine and sucrose seeking in rats. Behav Brain Res 281:125-130, 2015

18. Guo L, Zhou H, Wang R, Xu J, Zhou W, Zhang F, et al: DBS of nucleus accumbens on heroin seeking behaviors in selfadministering rats. Drug Alcohol Depend 129:70-81, 2013

19. Hamilton J, Lee J, Canales JJ: Chronic unilateral stimulation of the nucleus accumbens at high or low frequencies attenuates relapse to cocaine seeking in an animal model. Brain Stimul 8:57-63, 2015

20. Han B, Compton WM, Blanco C, Crane E, Lee J, Jones CM: Prescription opioid use, misuse, and use disorders in U.S. adults: 2015 National Survey on Drug Use and Health. Ann Intern Med 167:293-301, 2017

21. Heinze HJ, Heldmann M, Voges J, Hinrichs H, Marco-Pallares J, Hopf JM, et al: Counteracting incentive sensitization in severe alcohol dependence using deep brain stimulation of the nucleus accumbens: clinical and basic science aspects. Front Hum Neurosci 3:22, 2009

22. Heldmann M, Berding G, Voges J, Bogerts B, Galazky I, Müller U, et al: Deep brain stimulation of nucleus accumbens region in alcoholism affects reward processing. PLoS One 7:e36572, 2012

23. Henderson MB, Green AI, Bradford PS, Chau DT, Roberts DW, Leiter JC: Deep brain stimulation of the nucleus accumbens reduces alcohol intake in alcohol-preferring rats. Neurosurg Focus 29(2):E12, 2010

24. Hu WH, Bi YF, Zhang K, Meng FG, Zhang JG: Highfrequency electrical stimulation in the nucleus accumbens of morphine-treated rats suppresses neuronal firing in rewardrelated brain regions. Med Sci Monit 17:BR153-BR160, 2011

25. Jha P, Ramasundarahettige C, Landsman V, Rostron B, Thun M, Anderson RN, et al: 21st-century hazards of smoking and benefits of cessation in the United States. N Engl J Med 368:341-350, 2013

26. Johansen-Berg H, Gutman DA, Behrens TE, Matthews PM, Rushworth MF, Katz E, et al: Anatomical connectivity of the subgenual cingulate region targeted with deep brain stimulation for treatment-resistant depression. Cereb Cortex 18:1374-1383, 2008

27. Knapp CM, Tozier L, Pak A, Ciraulo DA, Kornetsky C: Deep brain stimulation of the nucleus accumbens reduces ethanol consumption in rats. Pharmacol Biochem Behav 92:474479, 2009

28. Knobel D, Aybek S, Pollo C, Vingerhoets FJ, Berney A: Rapid resolution of dopamine dysregulation syndrome (DDS) after subthalamic DBS for Parkinson disease (PD): a case report. Cogn Behav Neurol 21:187-189, 2008

29. Koob GF: Drugs of abuse: anatomy, pharmacology and function of reward pathways. Trends Pharmacol Sci 13:177-184, 1992
30. Koob GF, Le Moal M: Drug abuse: hedonic homeostatic dysregulation. Science 278:52-58, 1997

31. Koob GF, Volkow ND: Neurocircuitry of addiction. Neuropsychopharmacology 35:217-238, 2010

32. Kuhn J, Bauer R, Pohl S, Lenartz D, Huff W, Kim EH, et al: Observations on unaided smoking cessation after deep brain stimulation of the nucleus accumbens. Eur Addict Res 15:196-201, 2009

33. Kuhn J, Gründler TO, Bauer R, Huff W, Fischer AG, Lenartz $\mathrm{D}$, et al: Successful deep brain stimulation of the nucleus accumbens in severe alcohol dependence is associated with changed performance monitoring. Addict Biol 16:620-623, 2011

34. Kuhn J, Lenartz D, Huff W, Lee S, Koulousakis A, Klosterkoetter J, et al: Remission of alcohol dependency following deep brain stimulation of the nucleus accumbens: valuable therapeutic implications? J Neurol Neurosurg Psychiatry 78:1152-1153, 2007

35. Kuhn J, Möller M, Treppmann JF, Bartsch C, Lenartz D, Gruendler TO, et al: Deep brain stimulation of the nucleus accumbens and its usefulness in severe opioid addiction. Mol Psychiatry 19:145-146, 2014

36. Langleben DD, Ruparel K, Elman I, Busch-Winokur S, Pratiwadi R, Loughead J, et al: Acute effect of methadone maintenance dose on brain FMRI response to heroin-related cues. Am J Psychiatry 165:390-394, 2008

37. Lawrence AD, Evans AH, Lees AJ: Compulsive use of dopamine replacement therapy in Parkinson's disease: reward systems gone awry? Lancet Neurol 2:595-604, 2003

38. Leiphart JW, Valone FH III: Stereotactic lesions for the treatment of psychiatric disorders. J Neurosurg 113:1204-1211, 2010

39. Levy D, Shabat-Simon M, Shalev U, Barnea-Ygael N, Cooper A, Zangen A: Repeated electrical stimulation of reward-related brain regions affects cocaine but not "natural" reinforcement. J Neurosci 27:14179-14189, 2007

40. Lim SY, O'Sullivan SS, Kotschet K, Gallagher DA, Lacey $\mathrm{C}$, Lawrence AD, et al: Dopamine dysregulation syndrome, impulse control disorders and punding after deep brain stimulation surgery for Parkinson's disease. J Clin Neurosci 16:1148-1152, 2009

41. Liu HY, Jin J, Tang JS, Sun WX, Jia H, Yang XP, et al: Chronic deep brain stimulation in the rat nucleus accumbens and its effect on morphine reinforcement. Addict Biol 13:40-46, 2008

42. Luigjes J, van den Brink W, Feenstra M, van den Munckhof P, Schuurman PR, Schippers R, et al: Deep brain stimulation in addiction: a review of potential brain targets. Mol Psychiatry 17:572-583, 2012

43. Lynch WJ: Modeling the development of drug addiction in male and female animals. Pharmacol Biochem Behav 164:50-61, 2018

44. Ma Y, Chen N, Wang HM, Meng FG, Zhang JG: Inhibition of the reinstatement of morphine-induced place preference in rats by high-frequency stimulation of the bilateral nucleus accumbens. Chin Med J (Engl) 126:1939-1943, 2013

45. MacAskill AF, Cassel JM, Carter AG: Cocaine exposure reorganizes cell type- and input-specific connectivity in the nucleus accumbens. Nat Neurosci 17:1198-1207, 2014

46. Maisonneuve IM, Ho A, Kreek MJ: Chronic administration of a cocaine "binge" alters basal extracellular levels in male rats: an in vivo microdialysis study. J Pharmacol Exp Ther 272:652-657, 1995

47. Mantione M, van de Brink W, Schuurman PR, Denys D: Smoking cessation and weight loss after chronic deep brain stimulation of the nucleus accumbens: therapeutic and research implications: case report. Neurosurgery 66:E218, 2010

48. Martínez-Rivera FJ, Rodriguez-Romaguera J, Lloret-Torres 
ME, Do Monte FH, Quirk GJ, Barreto-Estrada JL: Bidirectional modulation of extinction of drug seeking by deep brain stimulation of the ventral striatum. Biol Psychiatry 80:682690,2016

49. Müller UJ, Sturm V, Voges J, Heinze HJ, Galazky I, Heldmann M, et al: Successful treatment of chronic resistant alcoholism by deep brain stimulation of nucleus accumbens: first experience with three cases. Pharmacopsychiatry 42:288-291, 2009

50. Müller UJ, Voges J, Steiner J, Galazky I, Heinze HJ, Möller M, et al: Deep brain stimulation of the nucleus accumbens for the treatment of addiction. Ann N Y Acad Sci 1282:119-128, 2013

51. Naqvi NH, Rudrauf D, Damasio H, Bechara A: Damage to the insula disrupts addiction to cigarette smoking. Science 315:531-534, 2007

52. O'Brien CP, McLellan AT: Myths about the treatment of addiction. Lancet 347:237-240, 1996

53. Pascoli V, Terrier J, Espallergues J, Valjent E, O'Connor EC, Lüscher C: Contrasting forms of cocaine-evoked plasticity control components of relapse. Nature 509:459-464, 2014

54. Pascoli V, Turiault M, Lüscher C: Reversal of cocaine-evoked synaptic potentiation resets drug-induced adaptive behaviour. Nature 481:71-75, 2011

55. Porta M, Brambilla A, Cavanna AE, Servello D, Sassi M, Rickards H, et al: Thalamic deep brain stimulation for treatment-refractory Tourette syndrome: two-year outcome. Neurology 73:1375-1380, 2009

56. Pushparaj A, Hamani C, Yu W, Shin DS, Kang B, Nobrega $\mathrm{JN}$, et al: Electrical stimulation of the insular region attenuates nicotine-taking and nicotine-seeking behaviors. Neuropsychopharmacology 38:690-698, 2013

57. Ramôa CP, Doyle SE, Lycas MD, Chernau AK, Lynch WJ: Diminished role of dopamine D1-receptor signaling with the development of an addicted phenotype in rats. Biol Psychiatry 76:8-14, 2014

58. Rouaud T, Lardeux S, Panayotis N, Paleressompoulle D, Cador M, Baunez C: Reducing the desire for cocaine with subthalamic nucleus deep brain stimulation. Proc Natl Acad Sci U S A 107:1196-1200, 2010

59. Smeding HM, Goudriaan AE, Foncke EM, Schuurman PR, Speelman JD, Schmand B: Pathological gambling after bilateral subthalamic nucleus stimulation in Parkinson disease. J Neurol Neurosurg Psychiatry 78:517-519, 2007

60. Stelten BM, Noblesse LH, Ackermans L, Temel Y, VisserVandewalle V: The neurosurgical treatment of addiction. Neurosurg Focus 25(1):E5, 2008

61. Valencia-Alfonso CE, Luigjes J, Smolders R, Cohen MX, Levar N, Mazaheri A, et al: Effective deep brain stimulation in heroin addiction: a case report with complementary intracranial electroencephalogram. Biol Psychiatry 71:e35-e37, 2012

62. Vassoler FM, Schmidt HD, Gerard ME, Famous KR, Ciraulo DA, Kornetsky C, et al: Deep brain stimulation of the nucleus accumbens shell attenuates cocaine priming-induced reinstatement of drug seeking in rats. J Neurosci 28:8735-8739, 2008

63. Vassoler FM, White SL, Hopkins TJ, Guercio LA, Espallergues J, Berton O, et al: Deep brain stimulation of the nucleus accumbens shell attenuates cocaine reinstatement through local and antidromic activation. J Neurosci 33:14446-14454, 2013

64. Voges J, Müller U, Bogerts B, Münte T, Heinze HJ: Deep brain stimulation surgery for alcohol addiction. World Neurosurg 80:28.e21-28.e31, 2013
65. Volkow ND, Fowler JS, Wang GJ: The addicted human brain: insights from imaging studies. J Clin Invest 111:1444-1451, 2003

66. Volkow ND, Wang GJ, Fowler JS, Logan J, Gatley SJ, Hitzemann R, et al: Decreased striatal dopaminergic responsiveness in detoxified cocaine-dependent subjects. Nature 386:830-833, 1997

67. Wade CL, Kallupi M, Hernandez DO, Breysse E, de Guglielmo G, Crawford E, et al: High-frequency stimulation of the subthalamic nucleus blocks compulsive-like re-escalation of heroin taking in rats. Neuropsychopharmacology 42:18501859,2017

68. Warren N, O'Gorman C, Lehn A, Siskind D: Dopamine dysregulation syndrome in Parkinson's disease: a systematic review of published cases. J Neurol Neurosurg Psychiatry 88:1060-1064, 2017

69. Weiss F, Markou A, Lorang MT, Koob GF: Basal extracellular dopamine levels in the nucleus accumbens are decreased during cocaine withdrawal after unlimited-access self-administration. Brain Res 593:314-318, 1992

70. Wilden JA, Qing KY, Hauser SR, McBride WJ, Irazoqui PP, Rodd ZA: Reduced ethanol consumption by alcohol-preferring $(\mathrm{P})$ rats following pharmacological silencing and deep brain stimulation of the nucleus accumbens shell. J Neurosurg 120:997-1005, 2014

71. Wind JJ, Anderson DE: From prefrontal leukotomy to deep brain stimulation: the historical transformation of psychosurgery and the emergence of neuroethics. Neurosurg Focus 25(1):E10, 2008

72. Witjas T, Baunez C, Henry JM, Delfini M, Regis J, Cherif AA, et al: Addiction in Parkinson's disease: impact of subthalamic nucleus deep brain stimulation. Mov Disord 20:1052-1055, 2005

73. Wolf ME: Addiction: making the connection between behavioral changes and neuronal plasticity in specific pathways. Mol Interv 2:146-157, 2002

74. Zahm DS: An integrative neuroanatomical perspective on some subcortical substrates of adaptive responding with emphasis on the nucleus accumbens. Neurosci Biobehav Rev 24:85-105, 2000

75. Zhou H, Xu J, Jiang J: Deep brain stimulation of nucleus accumbens on heroin-seeking behaviors: a case report. Biol Psychiatry 69:e41-e42, 2011

\section{Disclosures}

Dr. Elias received support from Insightec for a non-study-related clinical or research effort that he oversaw.

\section{Author Contributions}

Conception and design: Wang, Elias, Lynch. Acquisition of data: Wang. Analysis and interpretation of data: all authors. Drafting the article: Wang. Critically revising the article: all authors. Reviewed submitted version of manuscript: all authors. Approved the final version of the manuscript on behalf of all authors: Wang. Study supervision: Elias, Lynch.

\section{Correspondence}

Tony R. Wang: University of Virginia, Charlottesville, VA. tw5tf@hscmail.mcc.virginia.edu. 